\title{
Thyroid function in male infertility
}

\author{
Elzbieta Krajewska-Kulak ${ }^{1}$ and Pallav Sengupta ${ }^{2}$ * \\ 1 Integrated Medical Care, Medical University of Bialystok, Bialystok, Poland \\ 2 Department of Physiology, Vidyasagar College for Women, University of Calcutta, Calcutta, West Bengal, India \\ *Correspondence: sunny_pallav_1984@yahoo.co.in \\ Edited by: \\ Janete Maria Cerutti, Universidade Federal de São Paulo, Brazil \\ Reviewed by: \\ Magnus R. Dias Da Silva, Universidade Federal de São Paulo, Brazil
}

Keywords: infertility, male reproduction, spermatogenesis, testosterone, thyroid hormones, TSH

\section{A commentary on}

The role of thyroid hormone in testicular development and function

by Wagner, M. S., Wajner, S. M., and Maia, A. L. (2008). J. Endocrinol. 199(3), 351-365. doi:10.1677/JOE-08-0218

Thyroid gland, previously supposed not to have any impact on spermatogenesis and male fertility, are now being recognized as having important role in male reproductive functions. Most of the studies on the effect of thyroid hormones on male fertility were conducted between the years 1970 and 2000 (1). The effects of thyroid hormone alterations on the reproductive system have been studied extensively in human subjects and animal models that have generally shown that changes from normal thyroid function resulted in decreased sexual activity and fertility $(2,3)$. The underlying mechanisms, however, are not constant throughout all species, and results from different studies disagree (4).

In rats rendered thyrotoxic by $\mathrm{T} 4$ resulted in decreased serum gonadotropin levels (5), decrease in total lipids, cholesterol, and phospholipids in testes, and synthesize increased amounts of testosterone (6). In immature male mice aged less than 4 weeks, the administration of slightly supra-physiological T4 doses resulted in a tendency toward early maturation and shortening of development period. Conversely, larger $\mathrm{TH}$ doses resulted in decreased testes weights and seminal vesicles, both in mice and rabbits (3). Direct effects of $\mathrm{T} 4$ resulted in minimal oxygen consumption changes in testes when $\mathrm{T} 4$ was present in testicular slice incubations (7). Finally, the effects of T4 on spermatogenesis are conflicting (8), but it would appear that T4 does not exert a direct effect on spermatogenesis in mature rats or rams (9). In rats, T3 affects testis maturation, and thyroid receptor (TR) type-1 (TR-1) expression in rats' testes $(10,11)$. Maximal Sertoli cell proliferation coincides with maximal $\mathrm{T} 3$ binding capacity in testis, suggesting that the main target of $\mathrm{T} 3$ action is the Sertoli cell. However, T3 also plays a significant role in differentiation of the seminiferous epithelium, and studies in rodents have shown that T3 is an important factor in maturation of Leydig cells. The presence of T3 is necessary to initiate differentiation of mesenchymal cells into Leydig progenitor cells, and $\mathrm{T} 3$ works in concert with other hormones [luteinizing hormone (LH) and IGF-I] to promote Leydig cell development (12). Data from other animal species (such as deer, sheep, cattle, birds, and mink) also suggest that $\mathrm{T} 3$ is a component of the neuroendocrine system that regulates seasonal cycles of reproductive activity (13). The underlying mechanisms postulate that $\mathrm{T} 3$ triggers cessation of reproduction at the end of the reproduction season because circulating T3 levels in deer rise at the time of seasonal transition to the nonbreeding state and thyroidectomy results in the absence of seasonal regression of the testis $(14,15)$. Hypothyroidism induced or occurring soon after birth was associated with marked sexual maturation and development delays in animals (16). Rats made hypothyroid transiently by propylthiouracil (PTU) administration showed a decrease in testicular size, retardation in Sertoli cell differentiation, and prolongation of Sertoli cell proliferation time (17). When the rats became older and returned to a euthyroid status, there was an increase in testis size, Sertoli cell number, and sperm production (18). In other studies where experimental hypothyroidism in rats and rams was left untreated for more than 1 month, there was an arrest of sexual maturity, decreased testosterone concentration as well as an absence of libido and ejaculate $(6,19)$. It would therefore appear that hypothyroidism affects the immature, but not the mature, testis. Pekary and Sattin (20) showed that both hypothyroidism and castration reduced TRH levels (20).

The two most common types of thyroid diseases are hypothyroidism and hyperthyroidism. Studies assessing the role of hypo- and hyperthyroidism in male infertility have also been conducted in human subjects. Hypothyroidism may result in a decrease in the sex hormone binding globulin (SHBG) levels and a decrease in total serum testosterone levels, as well as a decrease in the $\mathrm{LH}$ and the follicle stimulating hormone (FSH) levels (21). In cases of prolonged pre-pubertal hypothyroidism due to drop in $\mathrm{LH}$ and FSH levels, the Leydig and Sertoli cells, respectively are less stimulated to differentiate into mature cells, negatively affecting spermatogenesis. This increases the number of cells in the testes but decreases the number of mature cells. Thus, in patients with hypothyroidism, increased testicular size is observed along with a significant drop in mature germ cells within the seminiferous tubules $(22,23)$. Fortunately, hypothyroidism is very rare in males with an occurrence rate of only $0.1 \%$ in the general population (21). Among the studies on human subjects, Corrales Hernandez et al. (24) analyzed blood and semen samples of patients with primary hypothyroidism (24). The study concluded that hypothyroidism adversely affected semen quality by compromising semen volume and progressive sperm motility. Krassas 
et al. (25) conducted another study on human subjects with hypothyroidism (25). The authors reported abnormal sperm morphology and decreased motility in the patients. It is therefore evident that hypothyroidism adversely affects male fertility. Similarly, all the studies on hyperthyroidism also reported adverse effects on male reproductive organs and fertility. Clyde et al. by studying individual cases reported adverse effects of hyperthyroidism on semen quality (26). Clyde looked at three individual case studies of men with hyperthyroidism and infertility. Hormone levels were measured and recorded, and the overall results indicated that all three patients had low sperm counts as well as decreased sperm motility. However, such abnormalities were corrected when the patients were treated for thyroid disease. Therefore, Clyde concluded that male infertility is more common than previously thought in males with hyperthyroidism, possibly in correlation with elevated levels of testosterone, LH, and FSH. Hudson and Edwards (27) after conducting study on human subjects stated adverse effects of hyperthyroidism on spermatogenesis by altering sex steroid levels (27). Similarly, Krassas and Perros claimed adverse effects of hyperthyroidism on seminal parameters of human subjects (21). Most of the studies concerning hyperthyroidism were conducted on human subjects with only one conducted on rats. Rijntjes et al., in their study on rats concluded that hyperthyroidism delays Leydig cell development and adversely affects spermatogenesis (28).

\section{REFERENCES}

1. Singh R, Hamadaa AJ, Agarwal A. Thyroid hormones in male reproduction and fertility. Open Reprod Sci J (2011) 3:98-104. doi:10.2174/ 1874255601103010098

2. Sengupta P. Environmental and occupational exposure of metals and their role in male reproductive functions. Drug Chem Toxicol (2013) 36:353-68. doi:10.3109/01480545.2012.710631

3. Krassas GE, Poppe K, Glinoer D. Thyroid function and human reproductive health. Endocr Rev (2010) 31:702-55. doi:10.1210/er.2009-0041

4. Chandra AK, Goswami H, Sengupta P. Dietary calcium induced cytological and biochemical changes in thyroid. Environ Toxicol Pharmacol (2012) 34:454-65. doi:10.1016/j.etap.2012.06.003
5. Schneider G, Kopach K, Ohanian H, Bonnefond V, Mittler JC, Ertel NH. The hypothalamic pituitary-gonadal axis during hyperthyroidism in the rat. Endocrinology (1979) 105:674-9. doi:10. 1210/endo-105-3-674

6. Aruldhas MM, Valivullah HM, Srinivasan N, Govindarajulu P. Role of thyroid on testicular lipids in prepubertal, pubertal and adult rats. I. Hyperthyroidism. Biochim Biophys Acta (1986) 881:462-9. doi:10.1016/0304-4165(86) 90040- 1

7. Massie ED, Gomes WR, Van Demark NL. Effects of thyroidectomy or thyroxine on testicular tissue metabolism. J Reprod Fertil (1969) 18:173-4. doi:10.1530/jrf.0.0180173

8. Chandra AK, Sengupta P, Goswami H, Sarkar M. Excessive dietary calcium in the disruption of structural and functional status of adult male reproductive system in rat with possible mechanism. Mol Cell Biochem (2012) 364:181-91. doi:10.1007/s11010-0111217-3

9. Chandrasekhar Y, Holland MK, D'Occhio MJ, Setchell BP. Spermatogenesis, seminal characteristics and reproductive hormone levels in mature rams with induced hypothyroidism and hyperthyroidism. J Endocrinol (1985) 105:39-46. doi:10. 1677/joe.0.1050039

10. Buzzard JJ, Morrison JR, O’Bryan MK, Song Q, Wreford NG. Developmental expression of thyroid hormone receptors in the rat testis. Biol Reprod (2000) 62:664-9. doi:10.1095/ biolreprod62.3.664

11. Chandra AK, Sengupta P, Goswami H, Sarkar M. Effects of dietary magnesium on testicular histology, steroidogenesis, spermatogenesis and oxidative stress markers in adult rats. Indian J Exp Biol (2013) 51:37-47.

12. Mendis-Handagama SM, Ariyaratne HB. Differentiation of the adult Leydig cell population in the postnatal testis. Biol Reprod (2001) 65:660-71. doi:10.1095/biolreprod65.3.660

13. Dutta S, Joshi KR, Sengupta P, Bhattacharya K. Unilateral and bilateral cryptorchidism and its effect on the testicular morphology, histology, accessory sex organs and sperm count in laboratory mice. J Hum Reprod Sci (2013) 6:106-10. doi:10.4103/0974-1208.117172

14. Sengupta $P$. The laboratory rat: relating its age with humans. Int J Prev Med (2013) 4:624-30.

15. Sengupta P. Potential health impacts of hard water. Int J Prev Med (2013) 4:866-75.

16. Van Haaster LH, De Jong FH, Docter R, De Rooij DG. The effect of hypothyroidism on Sertoli cell proliferation and differentiation and hormone levels during testicular development in the rat. Endocrinology (1992) 131:1574-1576. doi:10. 1210/en.131.3.1574

17. Bunick D, Kirby J, Hess RA, Cooke PS. Developmental expression of testis messenger ribonucleic acids in the rat following propylthiouracil-induced neonatal hypothyroidism. Biol Reprod (1994) 51:706-13. doi:10.1095/biolreprod51.4.706
18. Gomes WR. Metabolic and regulatory hormones influencing testis function. In: Johnson AD, Gomes WR, Vandemark NL, editors. The Testis. Vol. III: Influencing Factors. New York: Academic Press (1970). 67 p.

19. Weiss SR, Burns JM. The effect of acute treatment with two goitrogens on plasma thyroid hormones, testosterone and testicular morphology in adult male rats. Comp Biochem Physiol A Comp Physiol (1988) 90:449-52. doi:10.1016/0300-9629(88) 90218-6

20. Pekary AE, Sattin A. Regulation of TRH and TRH related peptides in rat brain by thyroid and steroid hormones. Peptides (2001) 22:1161-73. doi:10.1016/S0196-9781(01)00429-6

21. Krassas GE, Perros P. Thyroid disease and male reproductive function. J Endocrinol Invest (2003) 26:372-80.

22. Krassas GE, Pontikides N. Male reproductive function in relation with thyroid alterations. Best Pract Res Clin Endocrinol Metab (2004) 18:183-95. doi: 10.1016/j.beem.2004.03.003

23. Wajner SM, Wagner MS, Maia AL. Clinical implications of altered thyroid status in male testicular function. Arq Bras Endocrinol Metabol (2009) 53:976-82. doi:10.1590/S000427302009000800011

24. Corrales Hernández JJ, García Miralles JM, Diez García LC. Primary hypothyroidism and human spermatogenesis. Arch Androl (1990) 25:21-7. doi: 10.3109/01485019008987590

25. Krassas GE, Papadopoulou F, Tziomalos K, Zeginiadou T, Pontikides N. Hypothyroidism has an adverse effect on human spermatogenesis: a prospective, controlled study. Thyroid (2008) 18:1255-9. doi:10.1089/thy.2008.0257

26. Clyde HR, Walsh PC, English RW. Elevated plasma testosterone and gonadotropin levels in infertile males with hyperthyroidism. Fertil Steril (1976) 27:662-6.

27. Hudson R, Edwards A. Testicular function in hyperthyroidism. J Androl (1992) 13:117-24.

28. Rijntjes E, Wientjes AT, Swarts HJ, de Rooij DG, Teerds KJ. Dietary-induced hyperthyroidism marginally affects neonatal testicular development. $J$ Androl (2008) 29:643-53. doi:10.2164/jandrol.108. 005108

Received: 17 September 2013; accepted: 28 October 2013; published online: 13 November 2013.

Citation: Krajewska-Kulak E and Sengupta P (2013) Thyroid function in male infertility. Front. Endocrinol. 4:174. doi: 10.3389/fendo.2013.00174

This article was submitted to Thyroid Endocrinology, a section of the journal Frontiers in Endocrinology. Copyright (c) 2013 Krajewska-Kulak and Sengupta. This is an open-access article distributed under the terms of the Creative Commons Attribution License (CC BY). The use, distribution or reproduction in other forums is permitted, provided the original author(s) or licensor are credited and that the original publication in this journal is cited, in accordance with accepted academic practice. No use, distribution or reproduction is permitted which does not comply with these terms. 